\title{
Biology and Impacts of Pacific Island Invasive Species. 5. Eleutherodactylus coqui, the Coqui Frog (Anura: Leptodactylidae) ${ }^{1}$
}

\author{
Karen H. Beard, ${ }^{2,5}$ Emily A. Price, ${ }^{3}$ and William C. Pitt ${ }^{4}$
}

\begin{abstract}
The nocturnal, terrestrial frog Eleutherodactylus coqui, known as the Coqui, is endemic to Puerto Rico and was accidentally introduced to Hawai'i via nursery plants in the late 1980s. Over the past two decades E. coqui has spread to the four main Hawaiian Islands, and a major campaign was launched to eliminate and control it. One of the primary reasons this frog has received attention is its loud mating call $(85-90 \mathrm{~dB}$ at $0.5 \mathrm{~m})$. Many homeowners do not want the frogs on their property, and their presence has influenced housing prices. In addition, E. coqui has indirectly impacted the floriculture industry because customers are reticent to purchase products potentially infested with frogs. Eleutherodactylus coqui attains extremely high densities in Hawai'i, up to 91,000 frogs $\mathrm{ha}^{-1}$, and can reproduce year-round, once every 1-2 months, and become reproductive around 8-9 months. Although the Coqui has been hypothesized to potentially compete with native insectivores, the most obvious potential ecological impact of the invasion is predation on invertebrate populations and disruption of associated ecosystem processes. Multiple forms of control have been attempted in Hawaili with varying success. The most successful control available at this time is citric acid. Currently, the frog is established throughout the island of Hawai'i but may soon be eliminated on the other Hawaiian Islands via control efforts. Eradication is deemed no longer possible on the island of Hawai'i.
\end{abstract}

The Coqui frog, Eleutherodactylus coqui (Thomas, 1966), is one of 27 reptiles and amphibians that have established in Hawai'i, where there are no native reptiles or amphibians (Kraus 2003). Eleutherodactylus coqui has occurred on the four main Hawaiian Islands,

${ }^{1}$ Support for this research came from the Jack Berryman Institute at Utah State University, the U.S. Fish and Wildlife Service, Hawai'i Invasive Species Council, and USDA/NWRC/APHIS/Wildlife Services. Manuscript accepted 26 October 2008.

${ }^{2}$ Department of Wildland Resources and the Ecology Center, Utah State University, Logan, Utah 843225230 .

${ }^{3}$ Department of Environment and Society and the Ecology Center, Utah State University, Logan, Utah 84322-5215.

${ }^{4}$ USDA/APHIS/WS/National Wildlife Research Center, Hilo Field Station, Hilo, Hawai'i 96721.

${ }^{5}$ Corresponding author (e-mail: karen.beard@usu .edu).

Pacific Science (2009), vol. 63, no. 3:297-316

(C) 2009 by University of Hawai'i Press

All rights reserved though it is now mostly found on the island of Hawai' $i$. It is still increasing its distribution on the island of Hawai' $i$ and has concerned residents mostly because of its loud mating call. Because E. coqui frogs from Hawai'i have already traveled to other locations (e.g., Guam), and it has invaded other parts of the world (e.g., other Caribbean islands), it is important to know how E. coqui impacts the Hawaiian Islands and the state of management of the E. coqui invasion.

\section{NAME}

Eleutherodactylus coqui (Thomas) is often referred to as the "Coqui," which originates from its distinctive call. The two-note call consists of a "ko" and a "kee." In Puerto Rico, the frog is often referred to as "coquí común" (Joglar 1998), which translates to "common Coqui," because it is the most abundant frog in Puerto Rico.

As the Latin meaning of the genus name implies, Eleutherodactylus frogs have individual 
(nonwebbed) toes. This genus is one of the largest frog genera, with over 525 species named, approximately $25 \%$ of which exist in the West Indies (Townsend 1996).

Phylum Chordata, class Amphibia, order Anura, family Leptodactylidae.

DESCRIPTION AND ACCOUNT OF VARIATION

\section{Species Description}

Although larger than most other Puerto Rican Eleutherodactylus species, E. coqui is a small frog. It is difficult to generalize its exact size, however, because like many of its other characteristics, body size is variable (Narins and Smith 1986). For example, at 1,000 m altitude in Puerto Rico, females have a mean snoutvent length (SVL) of $58 \mathrm{~mm}$, and males a mean SVL of $42 \mathrm{~mm}$; at $450 \mathrm{~m}$, females have a mean SVL of $48 \mathrm{~mm}$ and males a mean of $37 \mathrm{~mm}$; and at $10 \mathrm{~m}$, females average $36 \mathrm{~mm}$ and males $30 \mathrm{~mm}$ (Lopez 1999). Body size has also been found to increase from west to east in Puerto Rico (Fogarty and Vilella 2002).

Beard et al. (2008) measured 2,954 frogs at eight sites on the island of Hawai'i from $45 \mathrm{~m}$ to $610 \mathrm{~m}$ and found that the lowest mean SVL for a population was $32 \mathrm{~mm}$ for females and $28 \mathrm{~mm}$ for males, and the highest mean SVL for a population was $38 \mathrm{~mm}$ for females and $30 \mathrm{~mm}$ for males. The largest female found measured $49 \mathrm{~mm}$, and the largest male measured $39 \mathrm{~mm}$. Similar to the frogs in Puerto Rico, where females are around 29\% larger than males (Woolbright 1989), females were $21 \%$ larger than males in Hawai' $i$ (Beard et al. 2008). If there is a relationship between SVL and elevation or longitude in Hawai $i$, it is not discernible from the samples collected to date (Beard et al. 2008).

There is considerable variation in color and patterns between individuals. Some researchers have described a large number of color patterns (e.g., Schwartz and Henderson 1991, Joglar 1998). Woolbright (2005) simplified these and described six color patterns for frogs of the Luquillo Mountains of Puerto Rico: (1) an irregular set of round, light or red polka dots on the back (Spotted); (2) an interocular bar (Interocular bar); (3) a solid or mottled design with no noticeably strong clear stripes or dots (Unstriped); (4) a hairline middorsal stripe (Thin stripe); (5) a wider stripe than no. 4 (Wide stripe); and (6) two red or light dorsolateral stripes (Dorsolateral stripes). All of these color patterns, except no. 1, are shown in Figure 1.

\section{Distinguishing Features}

The native Puerto Rican amphibian fauna is dominated by 16 endemic species in the Eleutherodactylus genus. All are nocturnal and terrestrial, but $E$. coqui is the most abundant and widespread. The species are distinguished based on morphology and call. In addition, the other Eleutherodactylus species are more restricted in range and habitat; E. coqui is found across the island and uses a broader vertical distribution in the forest (from the forest floor to the canopy) than other species (Stewart and Woolbright 1996).

The species that E. coqui is mostly likely to be confused with in Puerto Rico is E. portoricensis. Morphologically the species are similar; however, E. portoricensis has a yellow or tan body with silver or white eyes and a white abdomen (Schwartz and Henderson 1991). In addition, this species has a very similar two-note call but with a slightly greater frequency (pitch) and shorter call timing (time between calls). Unlike E. coqui, E. portoricensis is restricted to high elevations.

Of the amphibian species that have been introduced to Hawai $\mathrm{i}$, E. coqui mostly resembles E. planirostris, the Cuban greenhouse frog. Its distribution in Hawai' $i$ is not well known, but it appears to be widespread across all four main islands. Features that distinguish this species are its reddish brown to brown body, reddish eyes, white abdomen, more pointed nose, and toe shape. The toes are long and slender, and the terminal disks truncated (Conant and Collins 1991). Its call is different than that of E. coqui; it produces short, soft chirps. Finally, E. planirostris is a tiny frog and typically grows to only $25 \mathrm{~mm}$, although it can be up to $36 \mathrm{~mm}$ (Conant and Collins 1991, Schwartz and Henderson 1991). 


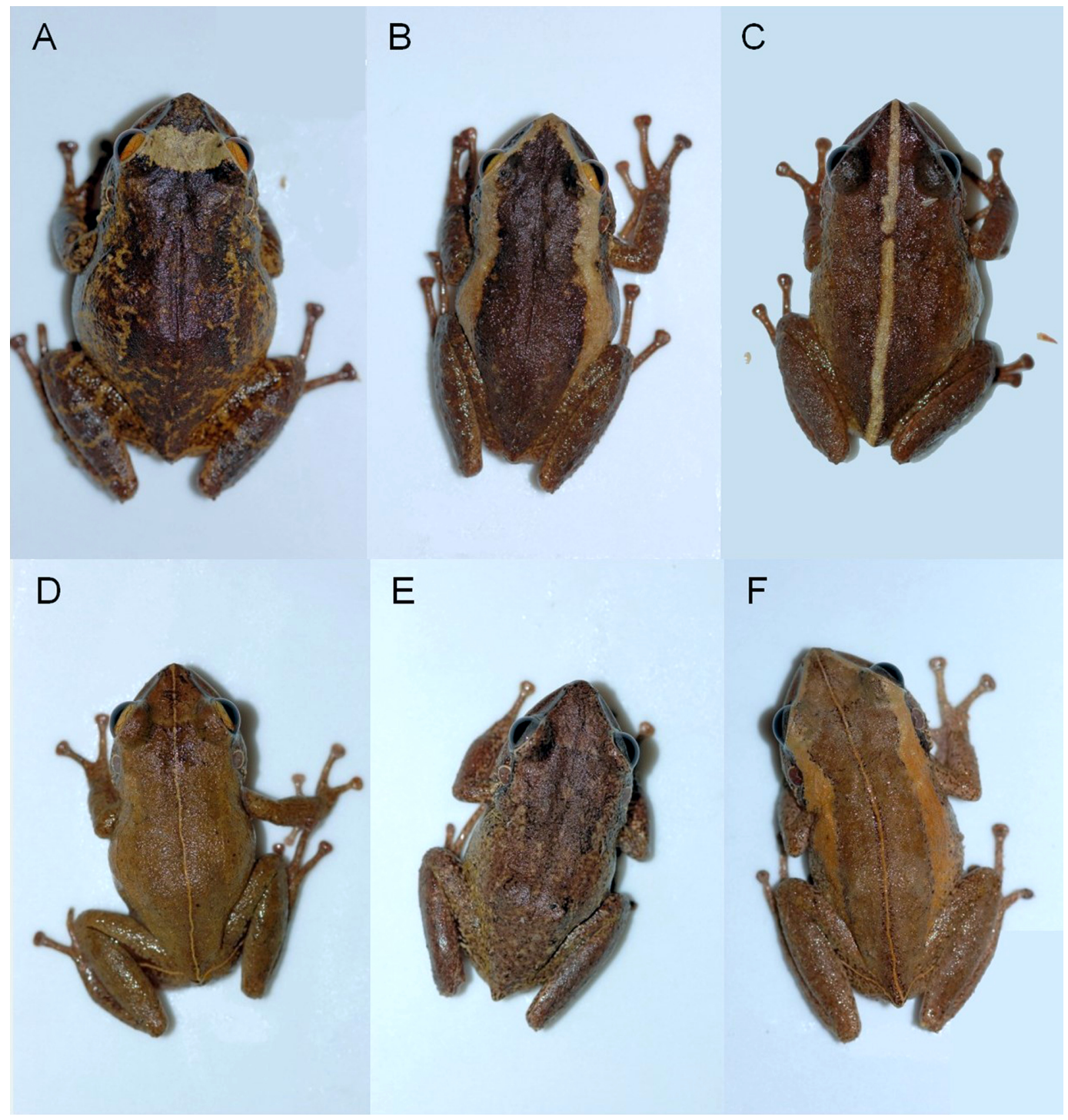

Figure 1. Stripe patterns in Eleutherodactylus coqui. $(A)$ interocular bar, $(B)$ dorsolateral stripes, $(C)$ wide middorsal stripe, $(D)$ narrow middorsal stripe, $(E)$ unstriped, $(F)$ multiple stripe patterns. (Photographer: Eric M. O’Neill)

Combinations of physical traits important for identifying E. coqui are as follows:

(1) Size: In Puerto Rico, SVL for males, 6 to $50.3 \mathrm{~mm}$; for females, 6 to $63 \mathrm{~mm}$ (Joglar 1998). In Hawai'i, SVL for males, 6 to $39 \mathrm{~mm}$; for females, 6 to $49 \mathrm{~mm}$.
(2) Body color: Undersides light gray and upper sides gray or gray brown (Rivero 1998).

(3) Color pattern: In Puerto Rico, interocular bar, unstriped, a hairline middorsal stripe, a wide middorsal stripe, two dorsolateral stripes, and combinations of these. In Hawai'i, interocular bar, 
narrow middorsal stripe, or unstriped (Figure 1) (O’Neill 2008).

(4) Eye color: In Puerto Rico, gray or golden, never white or silver (Rivero 1998). In Hawai'i, golden, which appears most consistent with populations on the eastern side of Puerto Rico (E. M. O'Neill, pers. comm.).

(5) Foot features: Toes lack webbing but possess well-developed pads.

(6) Disk size: Large relative to body size (see Figure 1) (Schwartz and Henderson 1991, Joglar 1998).

\section{ECONOMIC IMPORTANCE AND \\ ENVIRONMENTAL IMPACT}

\section{Detrimental Aspects}

Eleutherodactylus coqui has affected the floriculture industry and homeowners over the past $10 \mathrm{yr}$ in Hawai'i (Kraus et al. 1999, Kaiser and Burnett 2006). Direct economic impacts include reduced profits for plant nurseries, increased costs to the floriculture and nursery industry due to more stringent regulations, and changes in real estate value from increased noise pollution. Indirect economic impacts may also occur due to associated ecological changes.

Frogs are known to be spread through the movement of plant materials. Flowers and nursery product sales are the largest single agricultural commodity for the state and account for $15 \%$ of Hawai'i's \$621.6 million agricultural output (Hawai'i Agriculture Statistics Service [HASS] 2005). Nurseries that harbor frogs have experienced decreased sales due to the reluctance of consumers to purchase infested materials. In addition to decreasing sales, the increased costs to manage frogs also affect nurseries. At least two nurseries have closed or relocated because of $E$. coqui. Further, plant shipments have been refused entry or destroyed due to $E$. coqui by import personnel.

The main public concern surrounding $E$. coqui is noise nuisance (Figure 2). The call exceeds noise levels set to minimize interference with the enjoyment of life $(70 \mathrm{~dB}$ [Department of Health, Hawai'i Revised Statutes Section 324F-1]). Long-term expo- sure to a noise as loud as their call $(85-90$ $\mathrm{dB}$ at $0.5 \mathrm{~m}$ ) is the equivalent of listening to a lawnmower and may result in hearing damage (Centers for Disease Control [CDC] 1998). Residents in Hawai'i have reported difficulties in sleeping and participating in normal evening activities (Raloff 2003, Beamish 2004, Aguiar 2006).

Eleutherodactylus coqui may lower property values as potential buyers choose property free from E. coqui calls or are unwilling to pay as much for land that has frogs. The presence of E. coqui is now a part of the property disclosure requirement for property sales on the island of Hawai'i. Kaiser and Burnett (2006) evaluated the relationship of E. coqui complaints and housing prices from 1995 to 2005 throughout the island of Hawai' $i$. They found that a complaint of frogs within $500 \mathrm{~m}$ reduced property values by $0.16 \%$, and complaints within $500-800 \mathrm{~m}$ from a property reduced values by $0.12 \%$. When they projected these effects over all residential properties, direct damages to property values were estimated at a minimum of $\$ 7.6$ million (U.S. dollars used throughout text).

Costs of managing frog populations have been incurred by businesses and private landowners as well as county, state, and the federal government. For public agencies, the costs to assist in the management of frog populations exceeded \$4 million in 2007 (Hawai'i Invasive Species Council [HISC] 2007). Little or no data are available on the costs to businesses and landowners to manage frog populations. Estimates to eradicate frogs from the entire Hawaiian Island chain exceeded \$80 million in 2006 (Hawai'i Invasive Species Council 2007).

On the island of Hawai'i, where E. coqui is not considered eradicable, control efforts are now focused on treating small isolated populations to contain spread. The cost of current E. coqui detection and control on that island alone is \$2.8 million annually, and it has been estimated that it would cost another $\$ 6$ million annually to reach a more desirable level of detection and control; however, funding for this additional amount is not typically available (Hawai'i Invasive Species Council 2007). 


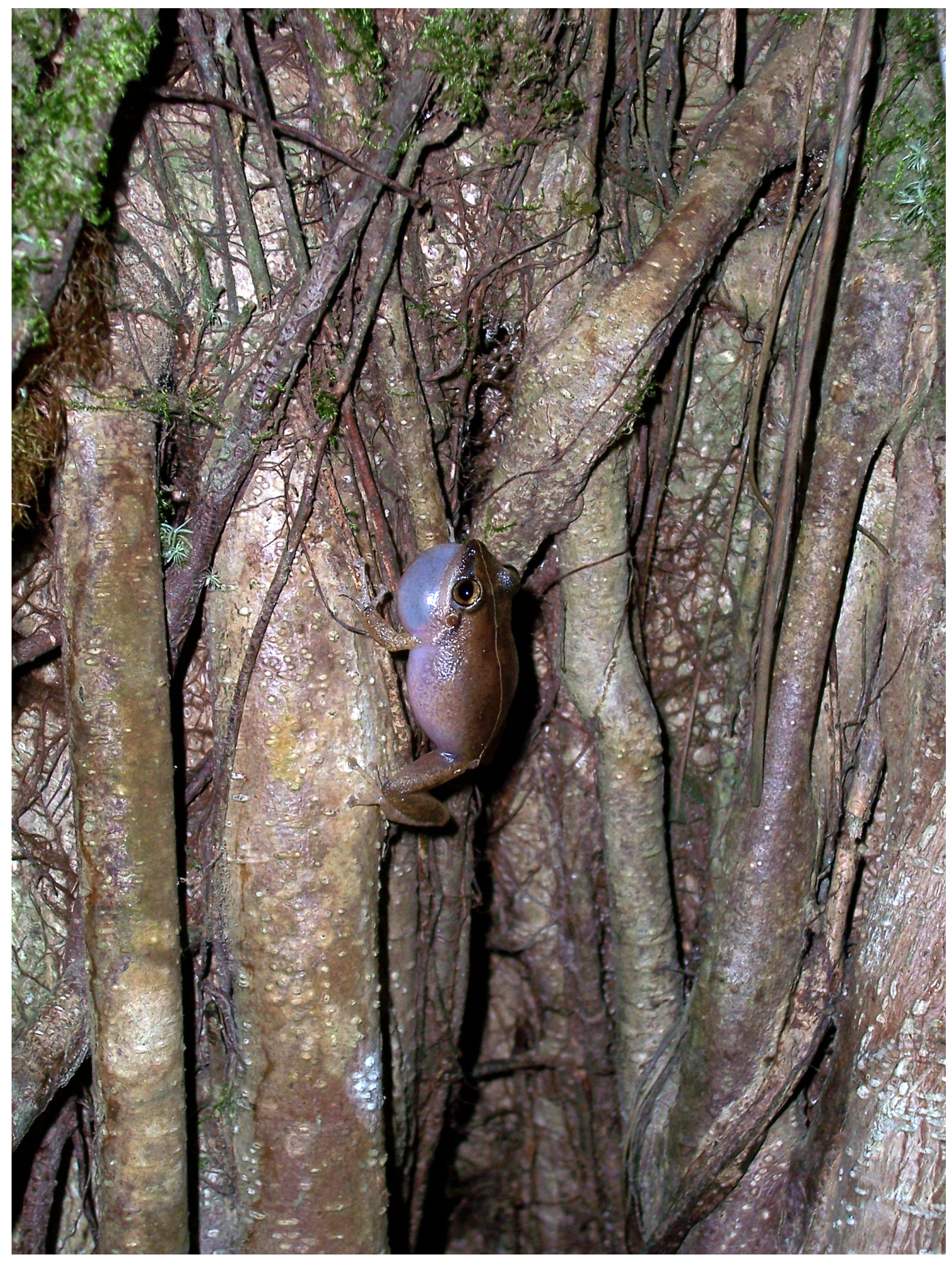

Figure 2. Photograph of calling male taken in Hawai i. (Photographer: Rogelio Doratt) 


\section{Beneficial Aspects}

Eleutherodactylus coqui is considered a national symbol in Puerto Rico (Joglar 1998), and it appears extensively on tourist items. In addition, frogs are depicted in all kinds of art forms, such as poems, songs, paintings, and musical compositions (Joglar 2003). There are estimated to be over 500 businesses in Puerto Rico that use the "Coqui" name, from Internet service providers, garbage collection services, restaurants, to gas stations (Joglar 2003).

Many in Hawai'i think the species is a nuisance, but others are more positive about the frog and have launched campaigns to save it (Kraus and Campbell 2002, Gonzalez-Pagan 2007). In both Puerto Rico and Hawai' $i$, some people state that the call reminds them of the countryside, and without the frog they would not be able to sleep (K. Beard and E. Price, pers. comm.). Because E. coqui are commonly found living in human-dominated landscapes, such as in homes and parks, they may reduce unwanted invertebrates.

\section{Regulatory Aspects}

All species in the order Anura (frogs) are Hawaici State Injurious Species. It is prohibited to release Injurious Species into the wild, transport them to islands or locations within the state where they are not already established, or export outside the state. It is also illegal to intentionally transport, harbor, or possess E. coqui within the state. In 2001, the Hawai'i Department of Agriculture designated E. coqui as a "pest" (Hawai'i Department of Agriculture 150A-2, Hawai'i Revised Statutes). The rule change was required to provide the department with the ability to mandate the treatment of $E$. coquiinfested materials. Nurseries that are considered infested and/or whose plant shipments have been found to be infested with the frog are required to treat plants with citric acid before any interisland shipment of plants. Plant materials exported from Hawai'i to Guam require treatment to remove E. coqui and a phytosanitary certificate before shipment.
In 2007, the California Department of Fish and Game placed E. coqui on the California restricted species list, which requires that the species can only be possessed under a permit (Duane Schnabel, pers. comm.). The species restriction provides state and local agencies with regulatory authority to inspect, stop shipment, quarantine, and destroy the species.

\section{Environmental Impacts}

Eleutherodactylus coqui has one of the highest densities of any terrestrial amphibian in the world. In Puerto Rico, densities have been found to vary from site to site and decrease with altitude from 45,000 frogs ha ${ }^{-1}$ at $30 \mathrm{~m}$ to 2,500 frogs ha $\mathrm{ha}^{-1}$ at $750 \mathrm{~m}$ (Stewart and Woolbright 1996). Thus, when E. coqui invaded Hawai' $i$, there was much concern about its environmental impacts (Kraus et al. 1999).

Because $E$. coqui is a generalist insectivore with high densities, the most likely environmental impact will be through predation on invertebrates and associated ecosystem disruption (Beard and Pitt 2005). This was of concern before research was conducted in Hawai'i, because Stewart and Woolbright (1996) found that E. coqui in Puerto Rico consumed an estimated 114,000 prey items/ha/ night. They also showed that E. coqui consumed a diversity of over 100 different prey, mostly herbivorous invertebrates and some leaf-litter and flying invertebrates (Townsend 1985, Woolbright 1985).

Beard (2007) determined E. coqui diets at sites on the islands of Hawai'i and Maui, and found that where they are occurring at densities as high as 91,000 frogs/ha, E. coqui could be consuming 690,000 invertebrates/ ha/night (Beard et al. 2008). Eleutherodactylus coqui was found to consume mostly leaf-litter invertebrates and some herbivorous and flying invertebrates (Beard 2007). Primary prey were ants, amphipods, and isopods, which composed $30 \%, 22 \%$, and $8 \%$ of the total prey consumed, respectively (Beard 2007). All individuals in these groups were identified as nonnative, perhaps due in part to the nonnative vegetation characteristic of the areas colonized. 
Eleutherodactylus coqui in Hawai'i does consume a wide diversity of prey, including: Acari (7\% of the prey items consumed), Collembola (10\%), Gastropoda (2\%), Diptera (3\%), and Coleoptera (5\%) (Beard 2007). Between $52 \%$ and $60 \%$ of the species in each of these groups (except Acari, which were not identified to species) at the invaded study sites were identified as possibly native, suggesting that natives in these orders are vulnerable to E. coqui predation. Sin et al. (2008) suggested that $E$. coqui could reduce invertebrates in Hawai' $i$ through direct predation.

A problem with diet analyses is that they fail to reveal the indirect effects of predation. For example, many of the invertebrates that E. coqui consumes play important roles in ecosystem processes, such as herbivory and decomposition of plant material. In Puerto Rico, herbivory rates were lower and plant growth and leaf litter decomposition rates were higher with than without E. coqui (Beard et al. 2003). Eleutherodactylus coqui was also found to increase the availability of nutrients, namely nitrogen and phosphorus, in throughfall and leaf litter (Beard et al. 2002).

At two study sites in Hawai'i, Sin et al. (2008) found that herbivory rates were lower and plant growth and leaf litter decomposition rates were higher with than without E. coqui. They also identified the pathway through which E. coqui has these effects: making nutrients more available to plants and microbes rather than through changes in the invertebrate community (Sin et al. 2008). In other words, E. coqui increased leaf litter decomposition rates by producing excrement rather than via consuming detritivores. Similarly, E. coqui increased plant growth rates by producing excrement rather than by consuming herbivores. These results also suggested that $E$. coqui has the potential to increase nutrient cycling rates in Hawaili, which may confer a competitive advantage to invasive plants in an ecosystem where native species have evolved under nutrient-poor conditions.

Other hypotheses regarding potential environmental impacts include E. coqui competing with other insectivores for prey, such as endemic birds or the endemic Hawaiian hoary bat (Kraus et al. 1999, Beard and Pitt
2005). However, no data have been collected to support or refute these hypotheses. In addition, it has been proposed that E. coqui may bolster introduced mammal populations, which are known bird predators. Beard and Pitt (2006) conducted diet analysis on mongoose and rat populations on the eastern side of the island of Hawai'i and found that $E$. coqui made up a small or negligible part of these small mammal diets. Finally, the current high density of frogs may increase the risk of unwanted predators of frogs becoming established, such as the brown tree snake.

\section{GEOGRAPHICAL DISTRIBUTION}

Eleutherodactylus coqui is native throughout the island of Puerto Rico, except in Mona or Desecheo (Joglar 1998). Eleutherodactylus coqui was introduced to Culebra and Vieques (Rivero and Joglar 1979), the Dominican Republic (Joglar 1998), and St. Thomas and St. Croix, Virgin Islands (MacLean 1982) (Figure 3). The establishment of E. coqui in Louisiana (Rivero 1984, Dundee 1991) is said to be a false report because it referred to a pet that eventually died. Eleutherodactylus coqui was introduced to Florida, probably to a botanical garden in Dade County in 1973, and is thought to have disappeared from that area in the late 1970s (Austin and Schwartz 1975, Wilson and Porras 1983). Populations were last reported in bromeliad nurseries in Dade County, Florida, in 2000 (Meshaka et al. 2004).

Eleutherodactylus coqui was introduced to the Hawaiian Islands in the late 1980s, probably around 1988 (Kraus et al. 1999, Kraus and Campbell 2002). There is some debate regarding whether E. coqui was first introduced to the island of Hawai'i or to Maui. According to the Maui Invasive Species Council, E. coqui was first identified on Maui in 1997, although there are reports of it being there as early as the late 1980s. The Hawai'i Invasive Species Council reported that $E$. coqui was first documented on O'ahu in 1998 and on Kaua'i in 1999.

Since the initial introduction, E. coqui has spread rapidly due to both accidental and intentional introductions. In 1998, there were 


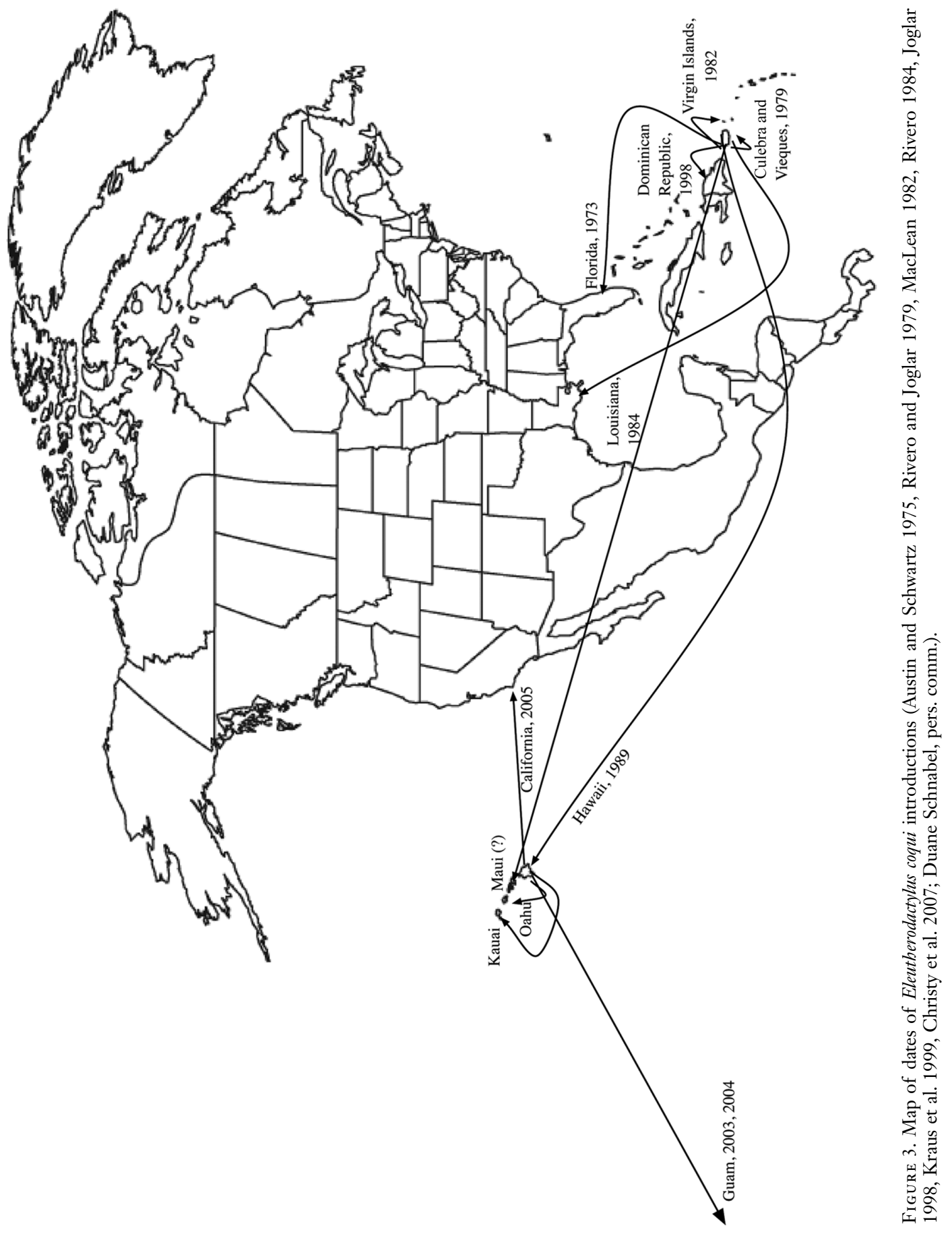


five documented populations on the island of Hawai'i and three on Maui (Kraus et al. 1999). By 2001, there were over 200 populations on the island of Hawai'i, 36 on Maui, 14 on $\mathrm{O}^{6} \mathrm{ahu}$, and two on Kaua'i (Kraus and Campbell 2002). The Big Island Invasive Species Council has documented continuing expansion of E. coqui range and new populations monthly. Between 2006 and 2007, E. coqui expanded its range on the island of $\mathrm{Ha}-$ wail $i$ from 2,800 ha to over 8,000 ha (Sin 2008).

At the time of writing, in part due to eradication efforts on Maui, O'ahu, and Kaua' $i$, Maui has only a handful of populations and one relatively large population at Māliko Gulch; O'ahu has no wild populations (populations outside of nurseries); and Kaua'i has only one small population. Islandwide eradication for these other islands is the focus and is thought to be possible.

There are reports of E. coqui in infested Hawaiian plant shipments that have reached Guam (2003 and 2004) and California (2005) (Campbell and Kraus 2002, Christy et al. 2007). In Guam, these introductions are believed to have been eradicated. There were two reports of E. coqui captured outside of nursery settings, but both individuals were eliminated, and no E. coqui has been detected subsequently (David Gee and Gordon Rodda, pers. comm.). In California, there were confirmed reports inside nursery greenhouses and commercial nurseries open to the public, but there were also unconfirmed outdoor reports at individual residences in the Los Angeles Basin (Duane Schnabel, pers. comm.). Eleutherodactylus coqui frogs are thought to still exist in California because local agencies and the California Department of Fish and Game continue to receive reports (Duane Schnabel, pers. comm.). Dates of known introductions throughout the world are displayed in Figure 3.

\section{HABITAT}

\section{Climatic Requirements and Limitations}

The habitat or selection requirements of this species have not been well studied, although microhabitat use and behavior are well quan- tified. Eleutherodactylus coqui exists almost everywhere in Puerto Rico where there is high humidity and adequate cover (Schwartz and Henderson 1991). Its absence is especially noted in the driest parts of the island (southwestern corner) and agricultural areas. Eleutherodactylus coqui is also found from sea level to the highest peak in Puerto Rico, around $1,200 \mathrm{~m}$.

Most populations in Hawai' $i$ are found in lowland $(0-500 \mathrm{~m})$ forests on the eastern side on the island of Hawai' $i$, the largest area of high precipitation (over 3,000 $\mathrm{mm}$ annually) (Price 1983). Eleutherodactylus coqui cannot survive on the highest peaks $(4,200 \mathrm{~m})$ because of freezing temperatures, but their elevational limit remains uncertain. The highest-elevation populations are currently around $1,200 \mathrm{~m}$. There are habitats above $1,200 \mathrm{~m}$ that may be suitable in terms of forest cover, although precipitation starts to decline at higher elevations (Price 1983). Currently, it is unclear whether E. coqui frogs are unable to establish at these higher elevations or whether they simply have not been introduced there.

\section{Habitat Resource Requirements and Limitations}

The primary factor thought to limit E. coqui in Puerto Rico is the amount of available nest and retreat sites (Stewart and Pough 1983, Woolbright 1996). This was most obviously observed after Hurricane Hugo in Puerto Rico, when habitat structure on the forest floor increased and was followed by a large increase in E. coqui density (Woolbright 1991, 1996). Thus, areas with denser undergrowth support greater densities (Fogarty and Vilella 2001). A highly significant positive relationship between the amount of understory habitat structure and E. coqui density has also been found in Hawai'i (Beard et al. 2008).

There is some support for the hypothesis that E. coqui may be prey limited in Puerto Rico. Beard (2001) found a positive relationship between $E$. coqui and invertebrate densities across study sites, and E. coqui reduced some invertebrates at small spatial scales. In addition, Woolbright (1989) found that growth rates of males and females slowed 
down as they grew larger in the field but not in the laboratory, where prey was abundant. However, support for the hypothesis that $E$. coqui are prey limited in Hawai' $i$ is weak. Beard et al. (2008) found a positive, although not significant, relationship between $E$. coqui and invertebrate densities across study sites. Eleutherodactylus coqui growth rates did not differ in the field and laboratory (Beard et al. 2008). In addition, E. coqui was found to avoid less-preferred prey at some sites, even though they consume these prey at other sites (Beard 2007), suggesting that at some sites they are not prey limited.

Moisture has been found to greatly influence E. coqui behavior. In Puerto Rico, where there is a great distinction between wet and dry seasons, frogs are much more active in terms of breeding (Townsend and Stewart 1994), foraging (Fogarty and Vilella 2002), and movement (Woolbright 1985) during the wet season. Many frogs, and especially juveniles, do not even emerge on dry nights. Other mechanisms used to reduce water loss include selection of moist habitats as retreat sites, and changes in postures to minimize surface area exposed (Pough et al. 1983, Townsend 1984).

\section{Ecosystem and Community Types Invaded}

As mentioned earlier, most populations in Hawai' $i$ are found in lowland $(0-500 \mathrm{~m})$ forests on the eastern side of the island of $\mathrm{Ha}$ wai' $i$. Even though densities are highest in forested habitats, E. coqui will readily use marginal habitats including human-altered ones, even buildings and houses (Joglar 1998). In Hawai'i, E. coqui populations have become established along roadsides and in nurseries, residential gardens, resort areas, refuse areas, and state parks. Most of the invaded habitats, even the lowland forests and state parks, are dominated by nonnative plants.

\section{HISTORY}

It is thought that E. coqui arrived in Hawai' $\mathrm{i}$ via nursery plants (Kraus et al. 1999), either from Puerto Rico or Florida. This is assumed because $E$. coqui first appeared in nurseries in
Hawai' $i$, and it had relatively stable populations in nurseries in Florida and Puerto Rico around the time of introduction. Because it appears that there are no longer any populations in Florida (Steven Johnson, pers. comm.), it would be difficult to determine genetically whether E. coqui came from Florida or Puerto Rico. However, it is possible to determine where these individuals may have originated in Puerto Rico.

Velo-Antón et al. (2007) made the first attempt to determine the origin of $E$. coqui in Hawai'i. They did this by sequencing cytochrome $b$ of the mitochondrial DNA (mtDNA) from 16 populations in Puerto Rico and three in Hawaili. Across Puerto Rico they found high levels of genetic variability, and two distinct clades, one in the eastern region and the other in the centralwestern region of the island $(5 \%-8 \%$ sequence divergence) (Velo-Antón et al. 2007). These clades are associated with the two main mountain ranges, and the level of divergence is considered high for individuals in the same species.

In contrast to Puerto Rico, no genetic variability was observed among the three $\mathrm{Ha}$ waiian study populations located across the southern part of the island of Hawai'i (VeloAntón et al. 2007). This supports the idea that this was an accidental introduction of only a few individuals. Of the 11 individuals studied across Hawai'i, only one haplotype was found. This haplotype revealed that the origins of the introduction were eastern Puerto Rico and more specifically the area around San Juan (where the primary ports are for that island). However, the sampling in Hawai' $i$ in this study was limited, and more intensive sampling is required to determine whether other haplotypes are present, potentially representing other independent introductions.

Although genetic variation has been studied using mtDNA (Velo-Antón et al. 2007), phylogeographic patterns in nuclear markers have not yet been investigated. Peters et al. (2008) described 13 microsatellite loci that can be used to investigate nuclear genetic structuring. These markers are currently being used by K.H.B. and colleagues 
to describe 13 populations in Puerto Rico and 15 populations across all four main islands in Hawaili.

Color patterns have also been used to investigate the origin and number of introductions into Hawai'i. O’Neill (2008) investigated five stripe patterns in 12 populations in Puerto Rico and 15 populations in Hawai' $i$ (Figure 1). In Puerto Rico, most populations had all stripe color patterns, with Unstriped as the most common pattern. In Hawaici, 14 of 15 populations had only two stripe patterns (Unstriped and Thin stripe), and a single population on Maui, Māliko Gulch, had two stripe patterns (Unstriped and Interocular bar) but not the same two as elsewhere in Hawai'i. Although genetic analyses have not been completed across the Hawaiian Islands, this suggests that there may have been a separate introduction into Maui.

\section{PHYSIOLOGY AND GROWTH}

As in other Eleutherodactylus, fertilized eggs of E. coqui undergo direct development, meaning that there is no free-living tadpole phase and complete metamorphosis occurs within the egg (Townsend and Stewart 1985, 1994). Young hatch as tiny froglets (Townsend and Stewart 1985). Males stay with the froglets for a few days after they emerge (Townsend and Stewart 1994).

Because E. coqui has direct development and is readily available, it has been the focus of much developmental research (Callery et al. 2001, Elinson 2001). The 15 development stages from fertilization to hatchling were described by Townsend and Stewart (1985); subsequent research focused on how its development differed from that of species that experience metamorphosis. Some of these studies illustrated the similarities between direct and indirect developers (Callery and Elinson 2000), and others described differences (e.g., Hanken et al. 2001, Buchholz et al. 2007). Because E. coqui has male parental care, there has also been a lot of interest in the physiological triggers associated with this (Townsend and Moger 1987, Townsend et al. 1991, Ten Eyck 2005).

Development rates decrease at higher altitudes due to lower temperatures. At 350 $\mathrm{m}$ elevation in Puerto Rico, Townsend and Stewart (1986b) observed a strong relationship between development period of egg clutches in E. coqui and mean daily ambient temperature. Development period shortened by 10 days with a $4^{\circ} \mathrm{C}$ increase in mean temperature (Townsend and Stewart 1986b). When the relationship between development rate and daily temperature for E. coqui was compared with that of other anurans, E. coqui exhibited unusual sensitivity to temperature (Townsend and Stewart 1986b).

Heart rate and oxygen consumption of $E$. coqui changes through egg development and as the frog grows. At temperatures of 24$25^{\circ} \mathrm{C}$, heart rate ranges between 50 and 130 beats min $^{-1}$ during development and between 80 and 85 beats $\min ^{-1}$ in large adult frogs (Burggren et al. 1990). Similarly, at temperatures of $24-25^{\circ} \mathrm{C}$, oxygen consumption is between 2 and $12 \mu \mathrm{mol} / \mathrm{g} / \mathrm{hr}$ during development, and for adults typically between 4 and $6 \mu \mathrm{mol} / \mathrm{g} / \mathrm{hr}$ (Burggren et al. 1990).

Amphibians, in general, are energy efficient, and E. coqui is no different. At $350 \mathrm{~m}$ elevation in Puerto Rico, Stewart and Woolbright (1996) estimated that E. coqui constitutes $6.0 \times 10^{4} \mathrm{~kJ} / \mathrm{ha}$ in biomass, consumes $1.1 \times 10^{6} \mathrm{~kJ} / \mathrm{ha} / \mathrm{yr}$, excretes $1.6 \times 10^{5} \mathrm{~kJ} / \mathrm{ha} /$ $\mathrm{yr}$, respires $3.9 \times 10^{5} \mathrm{~kJ} / \mathrm{ha} / \mathrm{yr}$, and uses $5.6 \times 10^{5} \mathrm{~kJ} / \mathrm{ha} / \mathrm{yr}$ for new production. Thus, conversion (production/assimilation) efficiencies were around $60 \%$, which is typical for amphibians.

Adult growth rates in the field were determined at $350 \mathrm{~m}$ elevation in Puerto Rico and across eight different elevations on the island of Hawai' $i$, thus caution should be used when comparing these rates. Using the equation for the relationship between SVL and growth rates presented in Woolbright (1989), Beard et al. (2008) found that male frogs in Hawai'i (on average $29 \mathrm{~mm}$ ) grow more slowly (around $0.008 \mathrm{~mm} /$ day) than would be predicted for similar-sized frogs in Puerto Rico (around $0.02 \mathrm{~mm} /$ day), and that females of similar size (on average $35 \mathrm{~mm}$ ) grow more slowly in Hawai'i (around $0.01 \mathrm{~mm} /$ day) than those in Puerto Rico (0.07 mm/day) (Woolbright 1989). 
REPRODUCTION AND POPULATION DYNAMICS

Most of the following data on reproduction is from Puerto Rico at an elevation of $350 \mathrm{~m}$. During the day, individuals use diurnal retreats near the forest floor (e.g., fallen, curled leaves, or belowground retreats typically in rocks). Individuals emerge from the retreats at dusk to forage and reproduce. Preadult males and females often forage in the canopy at dusk (Stewart 1985, Schwartz and Henderson 1991). Females approach calling males, which are often found closer to the forest floor; the males then lead the females to their retreat sites (nests) where amplexus occurs (Townsend and Stewart 1986a). Mating success of males is directly related to call effort (Lopez and Narins 1991, Townsend and Stewart 1994). Calling is energetically costly; males lose $16 \%$ of potential food consumption due to calling (Woolbright and Stewart 1987, Schwartz and Henderson 1991) and presumably expend additional energy generating their intense calls (Taigen and Wells 1985).

Maximum male calls occur between dusk and midnight with a strong secondary peak at dawn. Calling ramps up quickly at dusk and reaches full strength within a half hour of darkness (Woolbright 1985, Stewart 1995). Male frogs use the "ko" part of the call to interact with nearby males and the "kee" part to attract females. Thus, frogs can be heard calling with repeats of "ko" or "kee" as opposed to the more typically heard "ko - kee." The message conveyed depends on the repetition, intensity, and combination of notes (Stewart and Bishop 1994). Male aggressive calls are most often heard when the frogs move in and out of their retreat sites and are thought to aid in spacing (Stewart and Rand 1991). Both males and females call to defend their territory, but the females produce a softer rasping sound different than the two-note call of males (Schwartz and Henderson 1991, Stewart and Rand 1991, Joglar 1998).

In Puerto Rico, males will call between 1 and $15 \mathrm{~m}$ off the forest floor (Rivero 1998). Males often call from open, elevated perches, especially leaf surfaces, axils of palms, and tree trunks, located around $1-1.5 \mathrm{~m}$ from the forest floor (Townsend 1989). Similarly, adult males collected across nine sites on the island of Hawai' $i$ and two sites on Maui were found on average $0.9 \mathrm{~m}$ off the forest floor and on open, elevated surfaces, mostly leaves and trunks (Beard 2007).

In Puerto Rico, male calls vary with altitude (Narins and Smith 1986). Narins and colleagues found the following correlations with altitude: negative with frequency (pitch) of each note, positive with the length of each note, and positive with call timing (time between calls) (Narins and Smith 1986, Lopez and Narins 1991, Narins 1995). These relationships may be a result of size differences among conspecifics at different elevations (Blair 1964) or temperature differences (Narins and Hurley 1982, Pough et al. 1998).

The species utilizes internal fertilization (Townsend et al. 1981), and the fertilized eggs undergo direct development (as described earlier) (Townsend and Stewart 1985, 1994). Oviposition occurs within a few hours of insemination (Townsend and Stewart 1986a). Clutches contain about 28 eggs (range 16-41) (Townsend and Stewart 1994). Larger females lay more eggs than smaller females and larger males have more clutches than smaller males (Schwartz and Henderson 1991). Males guard the eggs, which hatch after 17-26 days, from water loss and predators (Taigen et al. 1984, Townsend 1989, Townsend and Stewart 1994).

As young frogs develop, they utilize habitats higher from the forest floor to forage. It requires around 8-9 months for frogs to attain sexual maturity (Stewart and Woolbright 1996), typically categorized as $>25$ mm SVL (Woolbright 2005). Eleutherodactylus coqui frogs reproduce year-round. Males breed close to monthly, and females breed about once every 2 months (Townsend and Stewart 1994). Annual mortality for preadults appears to be about $80 \%$, and $>90 \%$ for adults, with most individuals in the wild not likely living beyond $2 \mathrm{yr}$, with a maximum life expectancy of $6 \mathrm{yr}$ (Stewart and Woolbright 1996).

Density is typically determined by marking adult frogs (Woolbright 2005), and thus 
density estimates of adults are more accurate than total frog density. Long-term mean adult frog estimates from Puerto Rico range from 1 to 33/100 $\mathrm{m}^{2}$ (Stewart and Pough 1983, Woolbright 1991, Stewart and Woolbright 1996, Fogarty and Vilella 2002). Two studies have estimated density in Hawaici. Woolbright et al. (2006) estimated density at two study sites in the southeast of the island of Hawai'i for 2 yr, and Beard et al. (2008) estimated densities at those two sites and six others across the island for $3 \mathrm{yr}$. Woolbright et al. (2006) found higher densities at Lava Tree State Park (74-118 adults $/ 100 \mathrm{~m}^{2}$ ) than at $\mathrm{Pu}$ 'ainakō site $\left(34\right.$ adults/100 $\left.\mathrm{m}^{2}\right)$. Beard et al. (2008) found variability across sites with densities ranging from 11 to 112 adults/ $100 \mathrm{~m}^{2}$.

When calculating total density, and not just adult density, Woolbright et al. (2006) found that Lava Tree had 28,000-89,000 frogs/ha. Beard et al. (2008) found that total density ranged from 2,200 to 50,000 frogs/ha across the eight study sites over the 3 yrs. At four of the eight study sites, total frog densities were at least 1.7 times greater (35,000 frogs/ha) (Beard et al. 2008) than mean long-term estimates for the eastern mountains of Puerto Rico (20,570 frogs/ha; elevation $350 \mathrm{~m}$ ) (Stewart and Woolbright 1996). The highest total density estimate was for Manukā State Park in 2004, where densities were estimated to be 91,000 frogs/ha (Beard et al. 2008).

\section{RESPONSE TO MANAGEMENT}

\section{Chemical Control}

Chemical control is one of the few methods that has proven to be cost effective in controlling frogs over a large area (Campbell and Kraus 2002). Several chemicals are effective frog toxicants, but citric acid is the only chemical that can be used legally for controlling Eleutherodactylus frogs in Hawai'i at this time. The primary drawback of current chemical control methods is the need for the chemicals to contact frogs directly, and repeated applications may be necessary to ensure that all frogs and eggs are eliminated
(Pitt and Sin 2004a, Pitt and Doratt 2005, Tuttle et al. 2008).

Citric acid is classified as a minimum-risk pesticide and is exempt from the requirements of FIFRA by regulation (40 CFR Section 152.25). A 16\% citric acid solution (Pitt and Sin 2004a), and then later an 8\% citric acid solution (Pitt and Doratt 2006a), was found to be effective at controlling frogs in the laboratory, although its effectiveness may vary with environmental conditions and the physiological status of the frogs (Pitt and Sin 2004a). In field operations a citric acid solution as low as $11 \%$ has been effective in ground and aerial-based applications (Tuttle et al. 2008). Citric acid is not known to affect most nontarget arthropod invertebrates (Pitt and $\operatorname{Sin} 2004 b$ ). However, citric acid may result in some phytotoxic effects (e.g., pale spots on leaves) and may not be appropriate for all greenhouse plants (Figure 4) (Pitt and Sin $2004 d$ ). Due to these potential phytotoxic effects and relatively high cost ( $\$ 0.26 /$ liter $)$ citric acid may not be suitable for all situations.

In 2006, laboratory and field trials showed that endosulfan (Thionex 3EC), a restricteduse pesticide, was a highly effective frog toxicant that could be used to control frogs in floriculture and nursery areas (Pitt and Doratt 2006a,b). Endosulfan is an organochlorine insecticide that is widely used as a broadspectrum insecticide. Laboratory results determined that a $0.25 \%$ solution was an effective concentration resulting in $97 \%$ frog mortality after $24 \mathrm{hr}$ of initial exposure, and field trials conducted in a commercial greenhouse showed $60 \%$ decline in frog abundance within $48 \mathrm{hr}$ after treatment application and minimal phytotoxic effects on multiple varieties of orchids and different ornamental plants. Endosulfan-based pesticides may only be used in greenhouses and must be applied by a certified pesticide applicator.

Both a $2 \%$ caffeine solution and a $6 \%$ hydrated lime solution have been found to be effective frog toxicants in both laboratory and field settings, and have been shown to have minimal nontarget effects on arthropods (Campbell 2001, Pitt and Sin 2004c, Pitt and Doratt 2005). Caffeine was only legal for use 


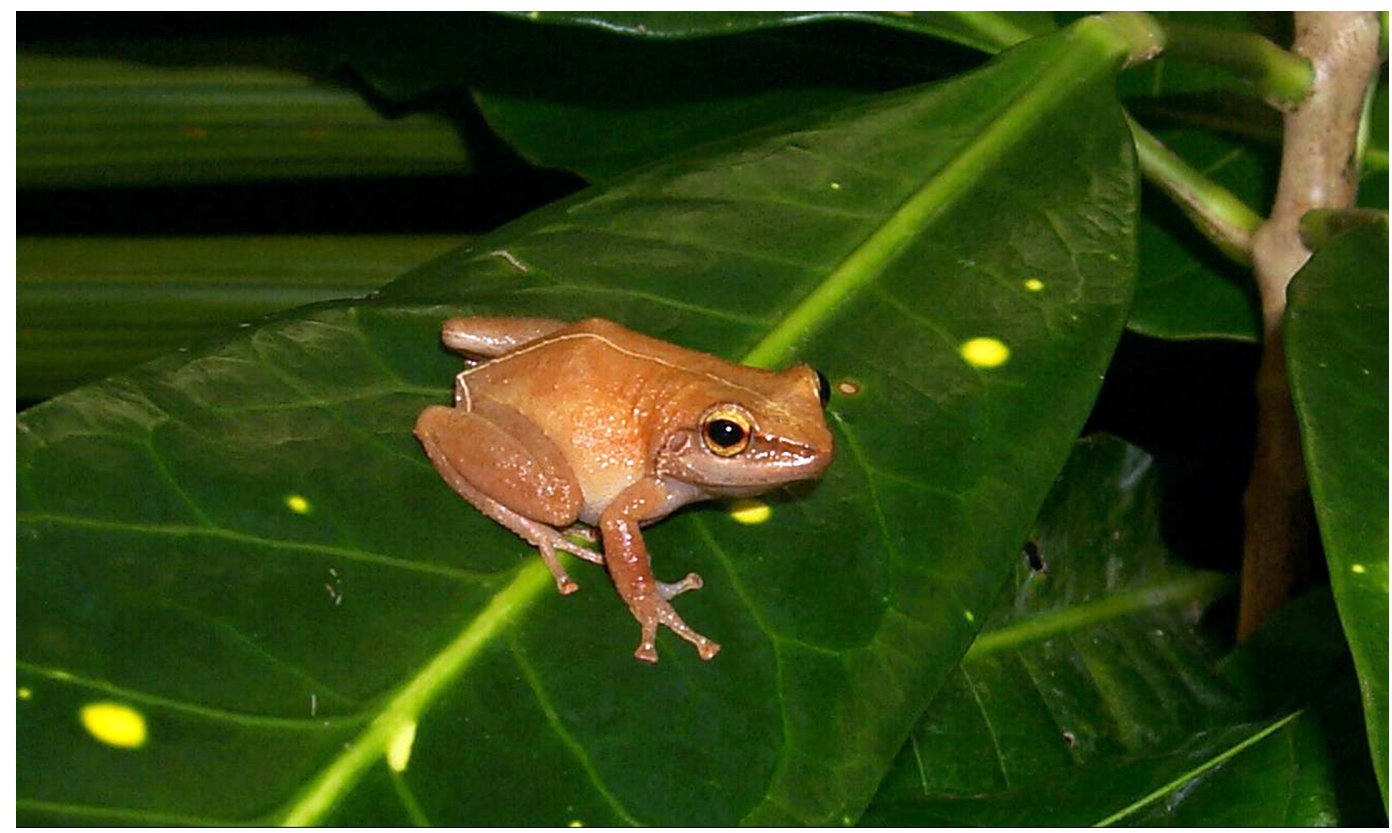

Figure 4. Photograph of Eleutherodactylus coqui on a leaf that has been treated with citric acid and is showing phytotoxic effects. (Photographer: Lori Oberhofer)

from October 2001 to September 2002 and was only used for registration and testing; it was never used operationally. Hydrated lime was legal for use from April 2005 to April 2008. Homeowners preferred hydrated lime over citric acid because of its lower cost of application ( $\sim 0.02 /$ liter $)$. However, hydrated lime persists as a white residue of calcium oxide on plants for several weeks, which is not a desirable feature in floriculture. At the time of writing, both caffeine and hydrated lime are no longer registered for use to control frogs.

\section{Mechanical Control}

Several mechanical control techniques have been evaluated for use in quarantine operations, nursery production, and for nonproduction areas. These techniques include hot water treatments, habitat management, handcapture, traps, and barriers.

Hot water or vapor heat treatments are an effective method for eliminating frogs and their eggs from potted plants for quarantine.
Hot water applied as a spray at $45^{\circ} \mathrm{C}$ for 3 min achieved up to $100 \%$ mortality (Arnold Hara, College of Tropical Agriculture and Human Resources, University of Hawai'i [CTAHR, UH], unpubl. data). In addition, vapor heat $\left(45^{\circ} \mathrm{C}, 90 \%\right.$ humidity $)$ was also effective. Orchids and bromeliads are sensitive to these heat treatments; this approach may not be preferred for high-value plants (Arnold Hara, CTAHR, UH, unpubl. data).

Habitat management may reduce the density of frog populations and reduce the likelihood that frogs will invade. Frog densities are typically higher in dense vegetation (Beard et al. 2008). Removing plants and dense vegetation, which can be focused on nonnative species, will likely reduce the number of frogs from a given area (Beard et al. 2008). Capturing individual frogs is effective only when a small number of frogs are present, all frogs can be located, and repeated attempts to capture animals are made (Beard 2001). Typically only adult males call; locating all pre-adults, females, and egg masses is challenging. Hand capture is a good option when 
the first one or two frogs appear in an area and they have not bred successfully.

Several barriers and traps have been developed and tested for frogs in Hawai'i. Traps made of bamboo or PVC pipe that provide refugia or nest sites for males have had limited effectiveness in capturing frogs, and they must be monitored regularly or they will encourage breeding (Sugihara 2000). These traps may be most effective if there are a small number of frogs and few natural retreat sites. A trap containing several calling males was effective at attracting females but did not trap many frogs. These traps might work best in a small, enclosed area, such as a greenhouse. Barriers made of fine flexible mesh to exclude frogs from quarantine areas are currently being investigated. Barriers would not eliminate frogs, would require maintenance, and could only be implemented on a small scale. The Hawai'i Department of Agriculture has been successful in excluding frogs with a simple barrier from small areas. Barriers may be most effective in greenhouses or quarantine areas.

\section{Biological Control}

Few biological control efforts for vertebrate pests have been successful (Hone 1994), and there appears to be no prospect for timely development of useful biological control technology for control of E. coqui. Even if an introduced predator or parasite were to reduce the density of E. coqui, this measure might not reduce the frogs to a reasonable level for residents and could have many unintended consequences for export businesses.

Unfortunately, the most frequently cited disease organisms [such as the iridovirus or the chytrid fungus Batrachochytrium dendrobatidis (Bd)] have a low potential for controlling E. coqui in Hawai' $i$, primarily because viruses and diseases are most effective when applied to small populations of species with low reproductive capacity (Brauer and CastilloChavez 2001, Daszak et al. 2003). In addition, most major frog diseases infect tadpole stages (Daszak et al. 2003), which E. coqui does not have. Bd has contributed to amphibian declines globally, and introduction of $\mathrm{Bd}$ has been suggested for Hawai' $i$, where there are no native frogs. However, E. coqui is relatively resistant (Carey and Livo 2008), and there is a chance that an infected frog could be transported to other states or countries (Beard and O'Neill 2005), which could affect frog populations elsewhere and restrict trade.

\section{NATURAL ENEMIES}

Most predation research on E. coqui has been conducted in its native range. Snails, flies, and E. coqui prey on E. coqui eggs in Puerto Rico (Schwartz and Henderson 1991). Anoles, skinks, other lizards, and invertebrates, such as crabs, crab spiders, wolf spiders, and whip spiders, prey upon young E. coqui (Stewart and Woolbright 1996). Larger frogs are less likely to be preyed upon by spiders because their increased body size enables them to more easily escape their captors (Formanowicz et al. 1981). Birds, such as owls, hawks, and thrushes, as well as snakes often prey on adult E. coqui (Stewart and Woolbright 1996, Joglar 1998). Mongooses and domestic cats also prey on E. coqui (Joglar 1998).

Although birds, invertebrates, and introduced mammals prey on E. coqui, none has been found to control their populations (Reagan and Waide 1996). One of the suspected reasons for higher densities of E. coqui in $\mathrm{Ha}-$ wai' $i$ is the lack of native predators and direct competition. The high density of $E$. coqui in Puerto Rico suggests that E. coqui in Hawai' $\mathrm{i}$ would likely be very abundant even with predators, competitors, and parasites. Beard and Pitt (2006) conducted diet analyses on mongooses, black rats, Polynesian rats, and cane toads on the eastern side of the island of Hawai'i. They found that E. coqui was not part of the diet of either rat species or the cane toad and made up only a small part of the mongoose diet. These findings are supported by studies done in Puerto Rico (Dexter 1932, Willig 1996, Vilella 1998).

There has also been some research on the parasites of E. coqui. Goldberg et al. (2007) described four helminth species found in $E$. coqui in Puerto Rico, but these species were not found in Hawai' $i$ frogs. The parasites in Hawai'i included Cosmocera sp. (57\% fre- 
quency in frogs collected), Physocephalus sp. (1\%), and the trematode Mesocoelium monas $(0.4 \%)$. Another study on parasites in E. coqui also found none of the same species of parasites on frogs in Puerto Rico and Hawai' $i$, with E. coqui in Hawai'i host to Cosmocera sp. and one species of Acanthocephala (Marr et al. 2008). The only species of parasite or pathogen in common in Puerto Rico and Hawai' $\mathrm{i}$ thus far is Bd (Burrowes et al. 2004, Beard and O’Neill 2005).

\section{PROGNOSIS}

Eleutherodactylus coqui populations are widespread throughout the island of Hawai' $i$ and complete eradication throughout the state of Hawai'i likely cannot be accomplished with current methods and available monetary resources. Small populations in residential or high-value ecological areas can be removed with effort, relatively modest resources, and currently available techniques. In addition, the effects of frogs where they are established and widespread can be minimized by managing vegetation, reducing populations with legal pesticides, and minimizing reinvasion. The spread of frogs to new areas can be avoided with good management techniques, such as inspecting and treating cargo and plant materials, using barriers, and not transporting material that is known to be infested.

\section{ACKNOWLEDGMENTS}

We thank Eric O'Neill for photographs of Coqui stripe patterns and USDA/APHIS/ WS/National Wildlife Research Center, Hilo Field Station, for the other photographs. We thank Gordon Rodda for a thorough review of the manuscript.

\section{Literature Cited}

Aguiar, E. 2006. Solution to coqui: A hot shower. Honolulu Advertiser (29 January 2006). http://the.honoluluadvertiser.com/ article/2006/Jan/29/ln/FP601290348.html.

Austin, D. F., and A. Schwartz. 1975. Another exotic amphibian in Florida, Eleutherodactylus coqui. Copeia 1975:188.
Beamish, R. 2004. Sleepless in HawaiiInsomniac islanders are hopping mad over a tiny frog that threatens their fragile ecosystem (Coqui frog). Smithsonian 34:2122.

Beard, K. H. 2001. The ecological roles of a terrestrial frog, Eleutherodactylus coqui (Thomas), in the nutrient cycles of a subtropical wet forest in Puerto Rico. Ph.D. diss., Yale University, New Haven, Connecticut.

- 2007. Diet of the invasive frog, Eleutherodactylus coqui, in Hawaii. Copeia 2007:281-291.

Beard, K. H., R. Al-Chokhachy, N. C. Tuttle, and E. M. O’Neill. 2008. Population density and growth rates of Eleutherodactylus coqui in Hawaii. J. Herpetol. 42:626636.

Beard, K. H., A. K. Eschtruth, K. A. Vogt, D. J. Vogt, and F. N. Scatena. 2003. The effects of the frog Eleutherodactylus coqui on invertebrates and ecosystem processes at two scales in the Luquillo Experimental Forest, Puerto Rico. J. Trop. Ecol. 19:607-617.

Beard, K. H., and E. M. O’Neill. 2005. Infection of an invasive frog Eleutherodactylus coqui by the chytrid fungus Batrachochytrium dendrobatidis in Hawaii. Biol. Conserv. 126:591-595.

Beard, K. H., and W. C. Pitt. 2005. Potential consequences of the coqui frog invasion in Hawaii. Divers. Distrib. 11:427-433.

2006. Potential predators of an invasive frog (Eleutherodactylus coqui) in Hawaiian forests. J. Trop. Ecol. 22:1-3.

Beard, K. H., K. A. Vogt, and A. Kulmatiski. 2002. Top-down effects of a terrestrial frog on nutrient dynamics. Oecologia (Berl.) 133:583-593.

Blair, W. F. 1964. Isolating mechanisms and interspecies interactions in anuran amphibians. Q. Rev. Biol. 39:333-344.

Brauer, F., and C. Castillo-Chavez. 2001. Mathematical models in population biology and epidemiology. Springer Verlag, New York.

Buchholz, D., S. Singamsetty, U. Karadge, S. Williamson, C. Langer, and R. Elinson. 2007. Nutritional endoderm in a direct 
developing frog: A potential parallel to the evolution of the amniote egg. Dev. Dyn. 236:1259-1272.

Burggren, W. W., R. L. Infantino, and D. S. Townsend. 1990. Developmental changes in cardiac and metabolic physiology of the direct-developing tropical frog Eleutherodactylus coqui. J. Exp. Biol. 152:129-147.

Burrowes, P., R. Joglar, and D. Green. 2004. Potential causes for amphibian declines in Puerto Rico. Herpetologica 60:141-154.

Callery, E., and R. Elinson. 2000. Thyroid hormone-dependent metamorphosis in a direct developing frog. Proc. Natl. Acad. Sci. U.S.A. 97:2615-2620.

Callery, E., H. Fang, and R. Elinson. 2001. Frogs without polliwogs: Evolution of anuran direct development. Bioessays 23:233-241.

Campbell, E. W. 2001. Dermal toxicity of selected agricultural pesticides, pharmaceutical products, and household chemicals to introduced Eleutherodactylus frogs. Report submitted to the Maui Invasive Species Committee and the Hawai'i Department of Land and Natural Resources. http://www.hear.org/alienspeciesinhawaii/ species/frogs/caffeinelabelforfrogs20011121 .pdf.

Campbell, E. W., III, and F. Kraus. 2002. Neotropical frogs in Hawaii: Status and management options for an unusual introduced pest. Pages 316-318 in R. M. Timm and R. H. Schmitz, eds. Proceedings of the 20th Vertebrate Pest Conference, University of California, Davis.

Carey, C., and L. Livo. 2008. To use or not to use the chytrid pathogen, Batrachochytrium dendrobatidis, to attempt to eradicate Coqui frogs from Hawai'i. 1st International Conference on the Coqui Frog, 7-9 February 2008, Hilo, Hawai'i, http://www.ctahr.hawaii.edu/coqui/ WEBCCareyFICCF.pdf.pdf.

Centers for Disease Control (CDC). 1998. Criteria for a recommended standard: Occupational noise exposure. Chapter 1, section 1.1 in National Institute for Occupational Safety and Health Publication No. 98-126.

Christy, M., J. Savidge, and G. Rodda. 2007.
Multiple pathways for invasion of anurans on a Pacific island. Divers. Distrib. 13:598-607.

Conant, R., and J. Collins. 1991. Reptiles and amphibians: Eastern/Central North America. Houghton Mifflin Co., Boston.

Daszak, P., A. A. Cunningham, and A. D. Hyatt. 2003. Infectious disease and amphibian population declines. Divers. Distrib. 9:141-150.

Dexter, R. R. 1932. The food habits of the imported toad Bufo marinus in the sugar cane sections of Puerto Rico. Bull. Int. Soc. Sugar Cane Technol. 74:1-6.

Dundee, H. A. 1991. When is an introduction not an introduction? Herpetol. Rev. 22:122.

Elinson, R. 2001. Direct development: An alternative way to make a frog. Genesis 29:91-95.

Fogarty, J. H., and F. J. Vilella. 2001. Evaluating methodologies to survey Eleutherodactylus frogs in montane forests of Puerto Rico. Wildl. Soc. Bull. 29:948-955.

. 2002. Population dynamics of Eleutherodactylus coqui in Cordillera Forest reserves of Puerto Rico. J. Herpetol. 36:193-201.

Formanowicz, D. R., Jr., M. M. Stewart, K. Townsend, F. H. Pough, and P. F. Brussard. 1981. Predation by giant crab spiders on the Puerto Rico frog Eleutherodactylus coqui. Herpetologica 37:125-129.

Goldberg, S. R., C. R. Bursey, and F. Kraus. 2007. Eleutherodactylus coqui (Puerto Rican coqui): Endoparasites. Herpetol. Rev. 38:183-184.

Gonzalez-Pagan, O. 2007. Hawaii residents' attitudes towards the management of an invasive frog species (Eleutherodactylus coqui). Undergraduate honors thesis, Cornell University, Ithaca, New York.

Hanken, J., T. Carl, M. Richardson, L. Olsson, G. Schlosser, C. Osabutey, and M. Klymkowsky. 2001. Limb development in a "nonmodel" vertebrate, the directdeveloping frog Eleutherodactylus coqui. J. Exp. Zool. 291:375-388.

Hawai'i Agriculture Statistics Service (HASS). 2005. Statistics of Hawaili agriculture. Hawai'i Department of Agriculture, 
USDA National Agriculture Statistics Service, Honolulu. http://www.nass.usda.gov/ Statistics_by_State/Hawaii/index.asp.

Hawai'i Invasive Species Council (HISC). 2007. Controlling the Coqui, from http://www.hawaiiinvasivespecies.org/hisc/ enews/20070319hiscenews02_coqui.html.

Hone, J. 1994. Analysis of vertebrate pest control. Cambridge University Press, Cambridge, United Kingdom.

Joglar, R. L. 1998. Los coquíes de Puerto Rico: Su historia natural y conservatión. University of Puerto Rico, San Juan.

. 2003. An island enchanted by frogs. Pages 201-211 in R. W. Henderson and R. Powell, eds. Islands and the sea: Essays on herpetological explorations in the West Indies. Contributions to Herpetology, Vol. 30. Society for the Study of Amphibians and Reptiles, Ithaca, New York.

Kaiser, B., and K. Burnett. 2006. Economic impacts of E. coqui frogs in Hawaii. Interdiscip. Environ. Rev. 8:1-11.

Kraus, F. 2003. Invasion pathways of terrestrial vertebrates. Pages 68-92 in G. M. Ruiz and J. T. Carlton, eds. Invasive species: Vectors and management strategies. Island Press, Washington, D.C.

Kraus, F., and E. W. Campbell. 2002. Human-mediated escalation of a formerly eradicable problem: The invasion of $\mathrm{Ca}-$ ribbean frogs in the Hawaiian Islands. Biol. Invasions 4:327-332.

Kraus, F., E. W. Campbell, A. Allison, and T. Pratt. 1999. Eleutherodactylus frog introductions to Hawaii. Herpetol. Rev. 30:2125.

Lopez, N. R. 1999. Variation in reproductive biology, physiology, morphology of Eleutherodactylus coqui (Anura: Leptodactylidae) along an altitudinal gradient. M.S. thesis, University of Puerto Rico, Rio Piedras.

Lopez, P. T., and P. M. Narins. 1991. Mate choice in the neotropical frog, Eleutherodactylus coqui. Anim. Behav. 41:757-772.

MacLean, W. P. 1982. Reptiles and amphibians of the Virgin Islands. Macmillan Caribbean, London, Basingstoke.

Marr, S. R., W. J. Mautz, and A. H. Hara. 2008. Parasite loss and introduced species: A comparison of the parasites of the Puerto Rican tree frog, (Eleutberodactylus coqui), in its native and introduced ranges. Biol. Invasions 10:1289-1298.

Meshaka, W. E., Jr., B. P. Butterfield, and J. B. Hauge. 2004. Exotic amphibians and reptiles of Florida. Krieger Publ. Co., Melbourne, Florida.

Narins, P. M. 1995. Frog communication. Sci. Am. August: 62-83.

Narins, P. M., and D. D. Hurley. 1982. The relationship between call intensity and function in Puerto Rican coqui (Anura: Leptodactylidae). Herpetologica 38:287295.

Narins, P. M., and S. L. Smith. 1986. Clinal variation in anuran advertisement calls: Basis for acoustic isolation? Behav. Ecol. Sociobiol. 19:135-141.

O’Neill, E. M. 2008. Evolutionary consequences of the introduction of Eleutherodactylus coqui in Hawaii. Ph.D. diss., Utah State University, Logan.

Peters, M. B., K. H. Beard, C. Hagen, E. M. O'Neill, K. E. Mock, W. C. Pitt, and T. C. Glenn. 2008. Isolation of microsatellite loci from the coqui frog, Eleutherodactylus coqui. Mol. Ecol. Res. 8:139-141.

Pitt, W. C., and R. E. Doratt. 2005. Efficacy of hydrated lime on Eleutherodactylus coqui and an operational field-application assessment on the effects on non-target invertebrate organisms. USDA/APHIS/WS/ NWRC, Hilo, Hawai'i.

. 2006a. Screening for the evaluation of selected chemicals and pesticides to control Eleutherodactylus frogs in Hawaii. USDA/APHIS/WS/NWRC, Hilo, Hawai'i.

. 2006b. Field efficacy and phytotoxicity trials of spray application of Thionex $3 \mathrm{EC}$ solution for controlling the introduced frog Eleutherodactylus coqui in floriculture and nursery crops in Hawaii. USDA/APHIS/WS/NWRC. Hilo, Hawai'i.

Pitt, W. C., and H. Sin. 2004a. Dermal toxicity of citric acid based pesticides to introduced Eleutherodactylus frogs in Hawaii. USDA/APHIS/WS/NWRC, Hilo, Hawai'i.

. 2004b. Field efficacy and invertebrate non-target hazard assessment of citric acid spray application for control of introduced 
Eleutherodactylus frogs in Hawaii. USDA/ APHIS/WS/NWRC, Hilo, Hawai'i. . 2004c. Invertebrate non-target hazard assessment of caffeine application for control of Eleutherodactylus frogs. USDA/ APHIS/WS/NWRC, Hilo, Hawai'i.

. 2004d. Testing citric acid use on plants. Landscape Hawaii, July/August: 512.

Pough, F. H., R. M. Andrews, J. E. Cadle, M. L. Crump, A. H. Savitzky, and K. D. Wells. 1998. Herpetology. Prentice-Hall, Upper Saddle River, New Jersey.

Pough, F. H., T. L. Taigen, M. M. Stewart, and P. F. Brussard. 1983. Behavioral modification of evaporative water loss by a Puerto Rican frog. Ecology 64:244-252.

Price, S. 1983. Climate. Pages 59-66 in R. W. Armstrong, ed. Atlas of Hawaii. University of Hawai'i Press, Honolulu.

Raloff, J. 2003. Hawaii's hated frogs: Tiny invaders raise a big ruckus. Sci. News 163:11.

Reagan, D. P., and B. Waide, eds. 1996. The food web of a tropical rain forest. University of Chicago Press, Chicago.

Rivero, J. A. 1984. Bromeliad frogs of Puerto Rico. J. Bromeliad Soc. 34:64-66.

. 1998. Los anfibios y reptiles de Puerto Rico. University of Puerto Rico Press, San Juan.

Rivero, J. A., and R. L. Joglar. 1979. Eleutherodactylus cochranae. Herpetol. Rev. 10:101.

Schwartz, A., and R. W. Henderson. 1991. Amphibians and reptiles of the West Indies: Description, distributions, and natural history. University of Florida Press, Gainesville.

Sin, H. 2008. Coqui frog research and management efforts on the Big Island. 1st International Conference on the Coqui Frog, 7-9 February 2008, Hilo, Hawaici, http://www.ctahr.hawaii.edu/coqui/ HSinDNLRDOFAWFICCF.pdf.pdf.

Sin, H., K. H. Beard, and W. C. Pitt. 2008. An invasive frog, Eleutherodactylus coqui, has top-down effects on new leaf production and leaf litter decomposition rates through nutrient cycling in Hawaii. Biol. Invasions 10:335-345.

Stewart, M. M. 1985. Arboreal habitat use and parachuting in a subtropical forest frog. J. Herpetol. 19:391-401.
. 1995. Climate driven population fluctuations in rain forest frogs. J. Herpetol. 29:437-446.

Stewart, M. M., and P. J. Bishop. 1994. Effects of increased sound level of advertisement calls on calling male frogs, Eleutherodactylus coqui. J. Herpetol. 28:4653.

Stewart, M. M., and F. H. Pough. 1983. Population density of tropical forest frogs: Relation to retreat sites. Nature (Lond.) 221:570-572.

Stewart, M. M., and A. S. Rand. 1991. Vocalizations and the defense of retreat sites by male and female frogs, Eleutherodactylus coqui. Copeia 1991:423-436.

Stewart, M. M., and L. L. Woolbright. 1996. Amphibians, Pages 363-398 in D. P. Reagan and R. B. Waide, eds. The food web of a tropical rain forest. University of Chicago Press, Chicago.

Sugihara, R. T. 2000. Coqui trap study summary. USDA/APHIS/WS/NWRC, Hilo, Hawai'i.

Taigen, T. L., F. H. Pough, and M. M. Stewart. 1984. Water balance of terrestrial anuran (Eleutherodactylus coqui) eggs: Importance of parental care. Ecology 65:248-255.

Taigen, T. L., and K. D. Wells. 1985. Energetics of vocalization by an anuran amphibian (Hyla versicolor). J. Comp. Physiol. B155:163-170.

Ten Eyck, G. 2005. Arginine vasotocin activates advertisement calling and movement in the territorial Puerto Rican frog, Eleutherodactylus coqui. Horm. Behav. 47:23232229.

Thomas, R. 1966. A new species of Antillean Eleutherodactylus. Q. J. Fla. Acad. Sci. 28:375-391.

Townsend, D. S. 1984. The adaptive significance of male parental care in a neotropical frog. Ph.D. diss., State University of New York, Albany.

. 1989. The consequences of microhabitat choice for male reproductive success in a tropical frog (Eleutherodactylus coqui). Herpetologica 45:451-458.

. 1996. Patterns of parental care in frogs in the genus Eleutherodactylus. Pages 229-239 in R. Powell and R. W. Hender- 
son, eds. Contributions of West Indian herpetology: A tribute to Albert Schwartz. Contributions to Herpetology, Vol. 12. Society for the Study of Amphibians and Reptiles, Ithaca, New York.

Townsend, D. S., and W. H. Moger. 1987. Plasma androgen levels during male parental care in a tropical frog (Eleutherodactylus). Horm. Behav. 21:93-99.

Townsend, D. S., B. Palmer, and L. J. Guilette. 1991. The lack of influence of exogenous testosterone on male parental behavior in a neotropical frog (Eleutherodactylus) - a field experiment. Horm. Behav. 25:313-322.

Townsend, D. S., and M. M. Stewart. 1985. Direct development in Eleutherodactylus coqui (Anura: Leptodactylidae): A staging table. Copeia 1985:423-436.

1986a. Courtship and mating behavior of a Puerto Rican frog, Eleutherodactylus coqui. Herpetologica 42:165-170.

. 1986b. The effect of temperature on direct development in a terrestrialbreeding, neotropical frog. Copeia 1986:520-523.

. 1994. Reproductive ecology of the Puerto Rican frog Eleutherodactylus coqui. J. Herpetol. 28:34-40.

Townsend, D. S., M. M. Stewart, F. H. Pough, and P. F. Brussard. 1981. Internal fertilization in an oviparous frog. Science (Washington, D.C.) 212:469-471.

Townsend, K. V. 1985. Ontogenetic shift in habitat use by Eleutherodactylus coqui. M.S. thesis, State University of New York, Albany.

Tuttle, N. C., K. H. Beard, and R. AlChokhachy. 2008. Aerially applied citric acid reduces the density of an invasive frog in Hawaii, USA. Wildl. Res. 35(7): 676-683.

Velo-Antón, G., P. A. Burrowes, R. Joglar, I. Martínez-Solano, K. H. Beard, and G.
Parra-Olea. 2007. Phylogenetic study of Eleutherodactylus coqui (Anura: Leptodactylidae) reveals deep genetic fragmentation in Puerto Rico and pinpoints origins of Hawaiian populations. Mol. Phylogenet. Evol. 45:716-728.

Vilella, F. J. 1998. Biology of the mongoose (Herpestes javanicus) in a rain forest in Puerto Rico. Biotropica 30:120-125.

Willig, M. R. 1996. Mammals. Pages 399431 in D. P. Reagan and R. B. Waide, eds. The food web of a tropical rain forest. University of Chicago Press, Chicago.

Wilson, L. D., and L. Porras. 1983. The ecological impact of man on the South Florida herpetofauna. Univ. Kans. Mus. Nat. Hist. Spec. Publ. No. 9.

Woolbright, L. L. 1985. Patterns of nocturnal movement and calling by the tropical frog Eleutherodactylus coqui. Herpetologica 41:1-9.

.1989. Sexual dimorphism in Eleutherodactylus coqui: Selection pressures and growth rates. Herpetologica 45:68-74.

. 1991. The impact of Hurricane Hugo on forest frogs in Puerto Rico. Biotropica 23:462-467.

- 1996. Disturbance influences longterm population patterns in the Puerto Rican frog, Eleutherodactylus coqui (Anura: Leptodactylidae). Biotropica 28:493-501.

. 2005. A plot-based system of collecting population information on terrestrial breeding frogs. Herpetol. Rev. 36:139-142.

Woolbright, L. L., A. H. Hara, C. M. Jacobsen, W. J. Mautz, and F. L. Benevides. 2006. Population densities of the coqui, Eleutherodactylus coqui (Anura: Leptodactylidae) in newly invaded Hawaii and in native Puerto Rico. J. Herpetol. 40:122-126.

Woolbright, L. L., and M. M. Stewart. 1987. Foraging success of the tropical frog, Eleutherodactylus coqui: The cost of calling. Copeia 1987:69-75. 